\title{
PENGARUH PERCEIVED ORGANIZATIONAL SUPPORT, JOB DEMANDS, DAN JOB SATISFACTION TERHADAP WORK ENGAGEMENT
}

\author{
Muhammad Mudrik Fairnandha \\ Universitas Negeri Surabaya \\ muhammad.17080574057@mhs.unesa.ac.id
}

\begin{abstract}
This study aims to determine the effect of perceived organizational support, job demands and job satisfaction on work engagement among employees of SPBU COCO PT. Pertamina Retail Ketintang and Jemursari Surabaya. This research type is causal research that uses a quantitative approach. The sampling technique is total sampling, where the entire population was used as the sample. The sample that used is 60 respondents. The statistical analysis method is multiple linear regression with the help of the SPSS version 20 application. The results show that perceived organizational support has a significant effect on work engagement. Job demands have no significant effect on work engagement. Moreover, job satisfaction has no significant effect on work engagement. The company should pay more attention to decreasing their workers' satisfaction to maintain work engagement.
\end{abstract}

Keywords: job demands; job satisfaction; perceived organizational support; work engagement.

\section{PENDAHULUAN}

Persaingan bisnis antar perusahaan saat ini semakin ketat sehingga mewajibkan seluruh perusahaan untuk memaksimalkan segala sumber daya yang dimiliki oleh perusahaan tersebut, termasuk sumber daya manusia (Maria et al., 2017). Hal ini dikarenakan sumber daya manusia adalah elemen fundamental untuk keberlangsungan bagi setiap kegiatan bisnis (Wijayati et al., 2020). Menurut Vrchota et al. (2019), sumber daya manusia yakni angkatan kerja yang memiliki keterampilan dan dianggap sebagai suatu aset oleh perusahaan.

Sumber daya manusia yang unggul saja tidak cukup untuk menghadapi persaingan bisnis pada era modern ini, perusahaan membutuhkan sumber daya manusia yang terikat terhadap pekerjaannya sehingga mereka akan senantiasa memberikan usaha yang maksimal setiap kali melakukan pekerjaan (Jin \& McDonald, 2017). Menurut Kuok \& Taormina (2017), work engagement adalah keterikatan yang timbul pada karyawan karena hubungan dalam kegiatan organisasi secara kognitif, emosional, dan fisik sehingga menghasilkan pemikiran yang positif. Nugroho \& Savira (2019) mengemukakan work engagement merupakan salah satu penyebab psikologis yang vital untuk seseorang dalam melakukan pekerjaan dan diasumsikan dengan semangat (vigor), dedikasi (dedication), dan fokus (absorption). Work engagement yang tinggi pada pekerja akan menunjang perusahaan untuk maju dan berkembang menghadapi persaingan bisnis yang sedang terjadi (Amor et al., 2019).

Dunia pekerjaan di Indonesia seringkali menunjukkan karyawan dengan work engagement rendah sehingga perlu diketahui beberapa faktor yang dapat menjaga keterikatan pekerja untuk menjaga stabilitas perusahaan (Mujiasih, 2015). Salah satu bidang pekerjaan yang perlu memerhatikan work engagement pegawai mereka adalah perusahaan yang bergerak pada bidang pelayanan karena keterikatan mereka termasuk semangat dan dedikasi dalam melakukan pekerjaan dapat dirasakan langsung oleh konsumen selama proses pelayanan berlangsung (Yulianti \& Puteri, 2016). Salah satu perusahaan yang pokok kegiatannya berbasis pada bidang pelayanan adalah PT. Pertamina Retail di mana perusahaan ini adalah anak perusahaan dari PT. Pertamina Persero yang memiliki tugas pokok untuk menjual dan mendistribusikan bahan bakar minyak kepada masyarakat dengan mengelola Stasiun Pengisian Bahan Bakar Umum. Objek yang digunakan pada penelitian ini adalah SPBU COCO (Company Owned Company Operated) Ketintang dan Jemursari. Menurut hasil wawancara dengan Bapak Arif selaku pengawas SPBU Jemursari, kedua SPBU ini adalah objek percontohan bagi SPBU COCO lain di area Surabaya baik dari segi manajemen maupun dari segi pelayanan terhadap konsumen. Kedua SPBU ini juga seringkali mendapatkan penghargaan dari PT. Pertamina Retail atas kinerjanya dalam periode tertentu. Hal ini mengindikasikan bahwa keterikatan kerja dari pekerja di sana relatif 
tinggi, maka dipilihlah SPBU COCO Ketintang dan Jemursari sebagai objek penelitian ini untuk mengetahui apakah benar work engagement di sana tinggi dan apa saja faktor dan penyebabnya.

Banyak cara yang bisa dilakukan oleh perusahaan untuk meningkatkan work engagement pegawai (Fazlurrahman et al., 2020). Salah satu hal yang kemungkinan besar berdampak terhadap work engagement adalah perceived organizational support (Caesens \& Stinglhamber, 2014). Perceived organizational support adalah dukungan organisasi yang ditandai dengan rasa yakin perihal sejauh mana perusahaan mengevaluasi kinerja, meninjau kemakmuran pegawai, menanggapi kritik dan saran, menjamin kesejahteraan pekerja, dan memberdayakan pekerja dengan adil (Caesens et al., 2017). Perlakuan yang dapat dilakukan organisasi untuk meningkatkan perceived organizational support adalah memerhatikan tiga faktor, yakni keadilan, motivasi dari pimpinan, dan reward (Imran et al., 2020). Menurut hasil wawancara dengan Bapak Rudi selaku pengawas SPBU Ketintang, pihak manajemen selalu berusaha menyediakan apa yang dibutuhkan oleh pegawai untuk melakukan pekerjaan mereka dengan optimal. Sehingga, dengan baiknya dukungan organisasi yang diterima oleh pekerja, work engagement akan meningkat (Rais \& Parmin, 2020). Man \& Hadi (2013) mengemukakan pernyataan yang berbeda bahwa perceived organizational support berpengaruh positif namun bersifat lemah terhadap work engagement. Sehingga, diperlukan penelitian untuk membuktikan apakah perceived organizational support merupakan pengaruh yang kuat untuk meningkatkan work engagement.

Hal lain yang dapat memengaruhi work engagement dari pegawai, salah satunya adalah job demands (Ayu et al., 2015). Yeh (2015) menerangkan bahwa job demands yakni gabungan dari tuntutan-tuntutan pekerjaan yang mencakup ambiguitas, masalah peran, tingkat stress, tuntutan pekerjaan saat ini, dan pekerjaan yang belum selesai. Job demands dinilai menjadi sebuah bagian pekerjaan yang mencakup fisik, psikologis, maupun sosiologis yang mana membutuhkan usaha dalam pemenuhannya (Mokhtar et al., 2020). Dengan kata lain, job demands adalah tuntutan pekerjaan bagi karyawan untuk memenuhi visi perusahaan (Elst et al., 2016). Fenomena yang diamati di SPBU COCO Ketintang dan Jemursari adalah tuntutan pekerjaan terhadap karyawan di sana berpotensi memiliki tingkatan yang tinggi karena membutuhkan tenaga yang cukup banyak untuk melayani pelanggan selama satu shift kerja. Menurut Ahmed (2019), job demands yang diberikan terlalu tinggi oleh perusahaan akan menyebabkan perasaan tertekan dan dapat menurunkan work engagement yang dimiliki oleh karyawan tersebut, yang berarti hubungannya bersifat negatif. Namun, Jazilah (2020) menyatakan pendapat yang berbeda bahwa job demands berdampak signifikan positif terhadap work engagement, sehingga perlu diteliti kembali apakah job demands memang dapat memengaruhi work engagement dan apakah bentuk pengaruhnya bersifat positif atau negatif.

Faktor lainnya yang bisa berpengaruh terhadap work engagement adalah job satisfaction (Rugiyanto, 2018). Menurut Asbari et al. (2020), job satisfaction adalah perasaan positif seseorang bahwa pekerjaannya akan mencukupi nilai-nilai yang diharapkan. Fatmasari et al. (2018) mengemukakan beberapa indikasi untuk mengukur job satisfaction, antara lain asumsi bagi pekerjaan, asumsi bagi promosi, asumsi kepada rekan kerja, asumsi bagi situasi kinerja, dan asumsi bagi pengontrolan dari atasan. Menurut hasil wawancara dengan salah satu karyawan, terdapat beberapa kendala yang mereka alami terkait kepuasan kerja, salah satunya kondisi kerja yang kurang nyaman dan kendala terkait promosi, sehingga perlu diukur tingkat kepuasan kerja yang sebenarnya pada karyawan SPBU COCO Ketintang dan Jemursari. Dewantara \& Wulanyani (2019) mengemukakan bahwa semakin besar job satisfaction, maka dapat meningkatkan work engagement yang mereka miliki. Namun, Prabowo \& Fathoni (2017) mengemukakan bahwa tidak ada hubungan yang positif maupun signifikan antara job satisfaction dan work engagement. Maka, perlu diteliti kembali apakah job satisfaction berpengaruh kuat terhadap work engagement.

Tujuan penelitian ini adalah untuk mengetahui tingkat work engagement dari karyawan pada objek penelitian dan apakah variabel perceived organizational support, job demands, dan job satisfaction memang dapat berpengaruh terhadap work engagement. 


\section{KAJIAN PUSTAKA DAN PENGEMBANGAN HIPOTESIS}

\section{Perceived Organizational Support}

Pengertian dari perceived organizational support adalah kejadian di mana organisasi dapat memuaskan kebutuhan, menilai kontribusi serta memerhatikan keinginan dan ketertarikan karyawan (Akgunduz et al., 2018). Menurut Al Adresi \& Darun (2017), perceived organizational support adalah kepercayaan umum pekerja perihal sejauh mana perusahaan menilai pekerjaaan mereka, dan peduli terhadap kesejahteraan mereka. Caesens et al. (2017) mengemukakan bahwa perceived organizational support adalah anggapan dari pekerja perihal kontribusi, dukungan yang didapat, dan tingkat kepedulian terhadap kesejahteraan karyawan yang diberikan oleh organisasi. Menurut Wahyuni \& Sulastri (2020), perceived organizational support adalah rasa yakin pekerja tentang sejauh mana perusahaan dapat menghargai kinerja dan mengerti keinginan mereka. Menurut Andamari (2019), perceived organizational support adalah suatu hal yang memelajari bagaimana cara mendapatkan keuntungan dari karyawan melalui peningkatan komitmen mereka.

Zagenczyk et al. (2020) mengemukakan indikator pengukuran perceived organizational support yang berisi 8 indikator yakni: penghargaan terhadap kontribusi, kepedulian terhadap kesejahteraan, kepedulian terhadap kepuasan kerja, penilaian terhadap prestasi kerja, penghargaan terhadap usaha lebih, peduli terhadap keluhan, peneguran apabila terdapat kesalahan, dan perhatian besar terhadap karyawan.

\section{Job Demands}

Pengertian job demands adalah tuntutan atau dorongan dalam pekerjaan yang bersifat fisikal, psikologikal, sosial, dan membutuhkan upaya yang berkelanjutan (Elst et al., 2016). Menurut Maria et al. (2017), job demands didefinisikan sebagai konflik peran yang dialami oleh pegawai yang berhubungan dengan tuntutan pekerjaan dan keseimbangan dalam pekerjaan dan keluarga. Bakker \& Demerouti (2017) menyatakan bahwa job demands berkaitan erat dengan bidang psikologis, kejiwaan dan fisik. Menurut Mäkikangas et al. (2020), job demands adalah tuntutan pekerjaan yang diberikan perusahaan terhadap pekerja, tuntutan pekerjaan umumnya bisa mengakibatkan stress kerja dan dapat berpengaruh signifikan bagi kinerja seseorang. Menurut Ayu et al. (2015), job demands tidak selalu berdampak negatif namun dapat menjadi negatif jika diberikan terlalu tinggi. Jazilah (2020) mengemukakan indikator untuk pengukuran job demands di antaranya adalah: role ambiguity (ambiguitas peran), role conflict (peran yang bermasalah), dan work overload (beban kerja berlebih).

\section{Job Satisfaction}

Pengertian job satisfaction adalah anggapan jika pekerjaan mereka mencukupi kebutuhan yang bersifat material dan psikologis (Vorina et al., 2017). Menurut Dicke et al. (2019), kepuasan kerja adalah tingkatan dari kesukaan atau ketidaksukaan karyawan terhadap pekerjaan mereka dan juga harapan karyawan tentang pekerjaan yang diinginkan. Burić \& Moè (2020) menyatakan bahwa job satisfaction adalah definisi terkait kepuasan yang berhubungan dengan reaksi afektif yang bersifat positif dalam pekerjaan. Prabowo \& Fathoni (2017) menyatakan jika kepuasan kerja adalah sebuah dampak emosional dari pekerjaan. Widjaja \& Devie (2014) menyatakan jika job satisfaction mengasumsikan sejauh mana pekerja puas kepada pekerjaan mereka dan membentuk sikap-sikap yang bersifat positif bagi pekerjaan itu.

Lopes et al. (2015) mengemukakan beberapa indikator untuk mengukur job satisfaction, antara lain: sifat pekerjaan (nature of work), gaji saat ini (present pay), peluang mendapatkan promosi (opportunities for promotions), pengawasan (supervision), dan korelasi dengan rekan kerja (relationship with co-workers).

\section{Work Engagement}

Work engagement adalah pengalaman yang berkaitan dengan pemenuhan kebutuhan positif yang menyebabkan perilaku yang termotivasi di tempat kerja (Green et al., 2017). Menurut Amor et al. (2019), work engagement didefinisikan sebagai proses positif di mana seseorang mengekspresikan diri 
dengan mengatur diri mereka dan berperan dalam pekerjaan mereka. Eldor (2016) menyatakan bahwa work engagement adalah sebuah kondisi positif yang membentuk pekerja lebih terdorong saat menyelesaikan pekerjaannya yang diukur dengan sifat vigor, absorption, dan dedication. Najeemdeen et al. (2018) mengemukakan bahwa keterikatan karyawan digambarkan sebagai situasi yang diharapkan, sehingga menimbulkan keterlibatan, semangat, antusiasme, komitmen, upaya yang fokus, dan semangat. Menurut Vorina et al. (2017), keterikatan pekerja adalah keterampilan dan keinginan pekerja untuk kemakmuran perusahaan, dan kesediaan mereka untuk memberi usaha yang baik, melebihi apa yang dibutuhkan untuk mewujudkan kesuksesan perusahaan. Jin \& McDonald (2017) mengemukakan beberapa indikator untuk mengukur work engagement, yakni: vigor (semangat), dedication (dedikasi), dan absorption (penyerapan).

\section{Hubungan antar Variabel}

Al Adresi \& Darun (2017) menyatakan bahwa karyawan yang merasa kontribusinya dihargai oleh organisasi akan lebih menghargai hubungan baiknya dengan organisasi tersebut. Implementasi perceived organizational support dalam suatu perusahaan akan menentukan seberapa terikatnya pekerja dalam perusahaan tersebut (Imran et al., 2020). Caesens \& Stinglhamber (2014) menyatakan bahwa perceived organizational support dan work engagement memiliki hubungan yang kuat dan bersifat positif. Hal ini dikarenakan dukungan yang diberikan oleh organisasi menumbuhkan rasa diperhatikan pada karyawan sehingga dapat meningkatkan rasa terikat dalam pekerjaan mereka. Hal ini dibenarkan oleh Najeemdeen et al. (2018) yang melakukan penelitian terhadap staf universitas bisnis sebanyak 230 responden dengan teknik analisis regresi linier berganda dan menemui hasil jika perceived organizational support berdampak signifikan positif terhadap work engagement. Dwitasari et al. (2015) juga mendapati hasil yang sama dengan meneliti 327 karyawan di PT. Pupuk Kaltim dengan teknik analisis regresi linier berganda dan menyatakan jika perceived organizational support berdampak signifikan dan positif pada work engagement. Tetapi hal tersebut berbeda dengan Man \& Hadi (2013) yang mengemukakan jika perceived organizational support berdampak positif namun bersifat lemah terhadap work engagement.

\section{H1: Perceived organizational support berpengaruh terhadap work engagement.}

Job demands merupakan salah satu faktor yang memengaruhi work engagement (Bakker \& Demerouti, 2017). Job demands dapat menunjukkan asosiasi yang positif maupun negatif terhadap work engagement bergantung dari sifat job demands itu sendiri (Upadyaya et al., 2016). Maria et al. (2017) menyatakan bahwa job demands berkaitan dengan beban pekerjaan yang jika diberikan terlalu tinggi maka akan menimbulkan perasaan kurang nyaman dan dapat mengurangi rasa terikat karyawan terhadap pekerjaan mereka, namun juga dapat meningkatkan keterikatan kerja apabila diberikan dalam tingkatan yang ideal. Jazilah (2020) melakukan penelitian terhadap 32 karyawan pada PT. Bank Tabungan Negara dengan teknik analisis regresi linier berganda dan mendapati hasil bahwa job demands memengaruhi work engagement secara positif dan signifikan. Hal serupa dikemukakan oleh Ayu et al, (2015) yang meneliti 116 karyawan PT. Goodyear Indonesia dengan teknik analisis regresi linier berganda dengan hasil job demands berpengaruh positif dan signifikan terhadap work engagement. namun hal ini berbeda dengan Ahmed (2019) yang mengemukakan bahwa job demands bersifat negatif dan tidak memberikan pengaruh yang signifikan terhadap work engagement.

\section{$\mathrm{H} 2$ : Job demands berpengaruh terhadap work engagement.}

Terikatnya seorang karyawan pada suatu organisasi dan pekerjaan berawal dari rasa puas yang mereka dapatkan selama mereka bekerja (Mishra, 2013). Job satisfaction merupakan hal penting yang dapat memprediksi work engagement seseorang pada suatu organisasi (Guglielmi et al., 2016). Menurut Ali \& Farooqi (2014), job satisfaction memiliki pengaruh kuat dan bersifat positif terhadap work engagement, hal ini disebabkan oleh kepuasan dalam melakukan pekerjaan yang menimbulkan perasaan nyaman sehingga secara tidak langsung pekerja akan merasa memiliki ikatan dengan suatu organisasi. Vorina et al. (2017) meneliti karyawan publik di Slovenia sebanyak 594 responden dengan teknik analisis regresi linier sederhana dan mendapati hasil bahwa job satisfaction berpengaruh signifikan dan positif terhadap work engagement. Dewantara \& Wulanyani (2019) melakukan penelitian terhadap 
karyawan hotel swasta di Bali sebanyak 115 orang dengan menggunakan teknik analisis regresi linier berganda dan mendapatkan hasil bahwa job satisfaction berpengaruh positif dan signifikan terhadap work engagement. Namun hasil tersebut berbeda dengan Prabowo \& Fathoni (2017) yang mengemukakan bahwa job satisfaction tidak memiliki pengaruh yang signifikan terhadap work engagement.

H3: Job satisfaction berpengaruh terhadap work engagement.

\section{METODE PENELITIAN}

Metode penelitian ini adalah metode kuantitatif. Penelitian ini dilaksanakan di SPBU COCO PT. Pertamina Retail Ketintang dan Jemursari. Populasi dari penelitian ini sejumlah 60 karyawan. Metode sampling yang digunakan yakni sampling total yang mana seluruh jumlah populasi digunakan sebagai sampel. Teknik pengumpulan data menggunakan metode observasi, wawancara, dan penyebaran kuesioner. Skala pengukuran dalam penelitian ini adalah skala likert dengan range 1-5. Uji pengaruh yang digunakan antara lain uji regresi linier berganda, uji $\mathrm{T}$, uji $\mathrm{F}$, dan uji $\left(\mathrm{R}^{2}\right)$.

Dari hasil pengujian validitas pada setiap poin pernyataan dalam variabel perceived organizational support, job demands, job satisfaction dan work engagement sebanyak 44 item pernyataan, hanya 31 item pernyataan yang diasumsikan valid, di mana hal ini didapat dari perhitungan $r$ hitung $>r$ tabel. Pada pengujian reliabilitas, diperoleh poin cronbach alpha dalam variabel perceived organizational support sebesar 0,850 , job demands sebesar 0,908 , job satisfaction sebesar 0,745 dan work engagement sebesar 0,896 , yang berarti semua item pernyataan dinyatakan reliabel. Hal tersebut didasarkan dengan nilai cronbach alpha $>0,70$ (Ghozali, 2016).

\section{HASIL DAN PEMBAHASAN}

\section{Hasil Uji Asumsi Klasik}

Metode uji asumsi klasik pada penelitian ini adalah uji normalitas, uji multikolinieritas, dan uji heteroskesdatisitas. Dari uji normalitas letak titik pada P-P Plots berada pada sekeliling garis diagonal yang menandakan jika sebaran data bersifat normal. Pada pengujian one sample kolmogorov-smirnov (K-S) terdapat skor asymp sig. sejumlah 0,963 di mana skor tersebut lebih tinggi dibanding 0,05. Sehingga model regresi linier memiliki sebaran normal. Uji multikolinearitas menunjukkan variance inflation factor (VIF) pada variabel perceived organizational support sejumlah 1,739, job demands sejumlah 1,156, dan job satisfaction sebesar 1,571 di mana seluruh nilai dari variabel tersebut berada di bawah 10, sehingga tidak ditemukan gejala multikolinearitas penelitian ini. Uji heteroskedatisitas menunjukkan dalam grafik scatterplot sebaran titik-titik data tidak berpola dan tidak berkumpul di suatu tempat. Sehingga diasumsikan jika model regresi tidak mengalami fenomena heteroskedatsitas.

\section{Hasil Uji Hipotesis}

Uji $\left(R^{2}\right)$ menunjukkan nilai sejumlah 0.337 sehingga memberikan pernyataan jika variabel perceived organizational support, job demands dan job satisfaction mampu menjelaskan variabel work engagement sebesar $33,7 \%$, sementara $66,7 \%$ sisanya dapat dinilai korelasinya dari variabel-variabel lain yang tidak termasuk dalam model penelitian ini. Berdasarkan hasil dari pengujian regresi linier berganda, diperoleh persamaan (1).

Work Engagement $=11.569+0.361 \mathrm{X}_{1}-0.004 \mathrm{X}_{2}+0.322 \mathrm{X}_{3}+\mathrm{e}$.

Tabel 1 menunjukkan hasil uji t pada variabel perceived organizational support berpengaruh signifikan positif terhadap work engagement karena nilai t-hitung 3,323 > 2,003 t-tabel dengan tingkat signifikansi $0,024<0,05$. Variabel job demands tidak berpengaruh signifikan positif karena nilai t-hitung $-0,022<$ 2,003 t-tabel dengan tingkat signifikansi $0,982>0,05$. Begitu juga variabel job satisfaction tidak berpengaruh signifikan positif karena t-hitung 1,815 $<2,003$ t-tabel dengan tingkat signifikansi 0,075 $>0,05$. Hasil uji $\mathrm{F}$ menunjukkan nilai signifikansi sebesar $0,000<0,05$ dan nilai $\mathrm{F}$ hitung 10,979 > 
Muhammad Mudrik Fairnandha. Pengaruh Perceived Organizational Support, Job Demands, dan Job Satisfaction terhadap Work Engagement

2,38, sehingga perceived organizational support, job demands, dan job satisfaction secara bersamaan berpengaruh signifikan terhadap work engagement

Tabel 1.

HASIL UJI REGRESI LINEAR BERGANDA

\begin{tabular}{lcccccc}
\hline \multicolumn{1}{c}{ Variabel } & $\begin{array}{c}\text { Determinasi }\left(\mathbf{R}^{2}\right) \\
\text { Adj. } \boldsymbol{R} \text { Square }\end{array}$ & $\begin{array}{c}\text { Coefficient } \\
\mathbf{B}\end{array}$ & $\boldsymbol{T}$ & Sig. & $\boldsymbol{f}$ & Sig. \\
\hline (Constant) &, 337 & 11,569 & 2,323 &, 024 & 10,979 &, 000 \\
Perceived Organizational & & & & & & \\
Support (X1) & &, 361 & 3,125 &, 003 & & \\
Job Demands (X2) &,- 004 &,- 022 &, 982 & & \\
Job Satisfication (X3) &, 322 & 1,815 &, 075 & & \\
Sumber: Output SPSS (2021, data diolah) & & & & &
\end{tabular}

\section{Pengaruh Perceived Organizational Support terhadap Work Engagement}

Pengujian yang telah dilakukan menunjukkan bahwa perceived organizational support (X1) memberikan dampak signifikan dan positif terhadap work engagement $(\mathrm{Y})$ pada pegawai SPBU PT. Pertamina Retail Ketintang dan Jemursari. Hasil dari penelitian ini sejalan dengan Najeemdeen et al. (2018) serta Ramdhani \& Ratnasawitri (2017) yang mengemukakan jika perceived organizational support berdampak positif dan signifikan terhadap work engagement. Dengan kata lain, pekerja yang mendapatkan dukungan yang kuat dari perusahaan akan memiliki keterikatan kerja yang kuat pula (Imran et al., 2020). Hal ini dikarenakan dukungan organisasi atau perceived organizational support mendorong pekerja merasa lebih dihormati sebagai aset dari perusahaan, dan karyawan tanpa disadari akan terikat dengan pekerjaan mereka (Wahyuni \& Sulastri, 2020). Indikator penghargaan terhadap kontribusi dan kepedulian terhadap karyawan menunjukkan nilai yang tinggi. Hal ini membuktikan bahwa karyawan yang merasa dihargai dan dipedulikan oleh perusahaan akan memberikan timbal balik yang positif dan merasa terikat dengan pekerjaan mereka (Akgunduz et al., 2018).

Hasil wawancara tidak terstruktur pada beberapa karyawan SPBU PT. Pertamina Retail Ketintang dan Jemursari, didapatkan informasi bahwa karyawan merasa bahwa organisasi benar-benar berusaha untuk mendukung kegiatan kerja mereka, seperti pendapat dan keluhan yang diutarakan oleh karyawan selalu didengar dan dipertimbangkan oleh organisasi, penghargaan kontribusi yang dilakukan organisasi serta dukungan dan arahan dari atasan atau supervisor selama melakukan pekerjaan. Hal ini membuktikan bahwa organisasi yang selalu ada untuk karyawan akan memberikan dampak positif terhadap pekerjaan mereka (Caesens et al., 2017). Begitupun dengan hasil wawancara tidak terstruktur yang dilakukan dengan Bapak Rudi selaku pengawas SPBU Ketintang yang menyatakan bahwa perwakilan dari organisasi selalu mengusahakan untuk membuat karyawan merasa dihargai untuk tetap membuat mereka selalu maksimal dalam melakukan pekerjaan mereka. Pernyataan ini relatif serupa dengan ratarata jawaban responden yang menggambarkan bahwa mereka merasa dianggap dan diperhatikan selama mereka bekerja untuk organisasi. Sehingga kenyataan yang didapatkan di lapangan dan hasil penelitian dapat dikatakan selaras.

\section{Pengaruh Job Demands terhadap Work Engagement}

Pengujian yang telah dilakukan menunjukkan bahwa tidak ada pengaruh yang signifikan oleh job demands (X2) terhadap work engagement (Y) pada pegawai SPBU PT. Pertamina Retail Ketintang dan Jemursari. Hasil yang didapatkan dari penelitian ini sejalan dengan Ahmed (2019) dan Upadyaya et al. (2016) yang mengemukakan bahwa job demands tidak memberikan dampak yang signifikan terhadap work engagement dan hubungannya bersifat negatif, yang berarti jika tuntutan pekerjaan diberikan terlalu tinggi atau terlalu rendah, keterikatan kerja karyawan akan semakin rendah (Ahmed, 2019).

Hasil wawancara tidak terstruktur terhadap beberapa karyawan di SPBU Jemursari didapat informasi bahwa karyawan merasa pekerjaan mereka tidak terlalu banyak dan tidak harus bekerja dengan usaha ekstra untuk menyelesaikan pekerjaan. Menurut mereka, tuntutan yang diberikan oleh perusahaan selama ini belum sampai pada titik yang dapat memengaruhi keterikatan mereka terhadap pekerjaan. 
Hal ini selaras dengan jawaban dalam kuesioner yang sebagian besar menunjukkan tidak mengalami hal yang terlalu berarti terutama pada indikator beban kerja berlebih. Karena porsi beban kerja yang relatif rendah dapat menimbulkan kejenuhan pada karyawan dan dapat menurunkan keterikatan kerja (Elst et al., 2016). Sehingga, inilah yang menyebabkan variabel job demands tidak memberi dampak yang signifikan terhadap work engagement dikarenakan work engagement mereka masih berada dalam tingkatan yang tinggi, yang berarti kedua hal ini tidak berhubungan.

\section{Pengaruh Job Satisfaction terhadap Work Engagement}

Pengujian yang telah dilakukan menunjukkan bahwa tidak ada pengaruh yang signifikan yang ditimbulkan oleh job satisfaction (X3) terhadap work engagement (Y) pada pegawai SPBU PT. Pertamina Retail Ketintang dan Jemursari. Hasil yang diperoleh dari penelitian ini selaras dengan Affini \& Surip (2018) serta Humairoh \& Wardoyo (2017) yang mendapati hasil bahwa job satisfaction tidak berpengaruh secara signifikan terhadap work engagement karyawan, namun korelasinya bersifat positif. Yang berarti tingkat kepuasan kerja yang tinggi seharusnya dapat memperkuat work engagement karyawan (Fatmasari et al., 2018).

Dari hasil wawancara tidak terstruktur terhadap beberapa karyawan di kedua SPBU PT. Pertamina Retail, didapatkan informasi bahwa karyawan merasa kurang puas dengan jenjang karir atau kesempatan untuk mendapatkan promosi, mereka juga merasa bahwa kondisi lingkungan kerja mereka kurang kondusif dan tidak nyaman. Hal ini sama dengan jawaban pada kuesioner, terutama pada indikator sifat pekerjaan dan peluang mendapatkan promosi. Sebagian besar pegawai SPBU merasa kurang puas dengan pekerjaan mereka, namun keterikatan kerja mereka tetaplah tinggi yang berarti kedua hal ini tidak berhubungan dalam penelitian ini karena idealnya semakin puas pekerja dalam pekerjaan mereka, semakin tinggi pula keterikatan kerja mereka (Rugiyanto, 2018).

\section{Pengaruh Perceived Organizational Support, Job Demands, dan Job Satisfaction}

Pengujian yang dilakukan menunjukkan bahwa secara bersama-sama, variabel perceived organizational support (X1), job demands (X2), dan job satisfaction (X3) berdampak signifikan terhadap work engagement (Y) pegawai SPBU COCO PT. Pertamina Retail Ketintang dan Jemursari. Jika melihat hasil jawaban pada kuesioner, rata-rata jawaban responden pada variabel work engagement tergolong tinggi. Jika dilihat dari hasil wawancara secara tidak terstruktur kepada pengawas di kedua SPBU tersebut, keduanya menyetujui asumsi bahwa keterikatan kerja karyawan di sana tergolong tinggi. Hal ini tentunya dipengaruhi oleh sejumlah sebab, di antaranya adalah variabel perceived organizational support, job demands dan job satisfaction, walaupun masih ada variabel-variabel lain yang belum terobservasi dapat memengaruhi keterikatan kerja karyawan di perusahaan tersebut.

\section{KESIMPULAN}

Berdasarkan dari hasil penelitian dan pembahasan, diperoleh kesimpulan bahwa perceived organizational support berdampak signifikan dan positif terhadap work engagement. Semakin tinggi dukungan dari organisasi, semakin tinggi juga keterikatan kerja karyawan dari SPBU PT. Pertamina Retail Ketintang dan Jemursari. Kedua, job demands tidak menimbulkan pengaruh yang signifikan terhadap work engagement. Artinya, tingkat beban kerja yang didapat oleh karyawan tidak memengaruhi keterikatan dari karyawan SPBU COCO PT. Pertamina Retail Ketintang dan Jemursari. Ketiga, job satisfaction tidak menimbulkan dampak yang signifikan terhadap work engagement. Selanjutnya, hasil dari pengujian simultan menunjukkan perceived organizational support, job demands, dan job satisfaction berdampak signifikan terhadap work engagement.

Dari hasil penelitian ini, SPBU COCO PT. Pertamina Retail Ketintang \& Jemursari Surabaya disarankan untuk memerhatikan kembali dan memerbaiki hal-hal yang dapat menurunkan kepuasan kerja karyawan, terutama pada bidang pemerataan kesempatan promosi jabatan dan kondisi lingkungan kerja, sehingga keterikatan pekerja di sana yang sudah tergolong tinggi tetap terjaga. Penelitian selanjutnya dapat melibatkan variabel job resources, kompensasi, dan kinerja karyawan. 
Muhammad Mudrik Fairnandha. Pengaruh Perceived Organizational Support, Job Demands, dan Job Satisfaction terhadap Work Engagement

\section{DAFTAR PUSTAKA}

Affini, D. N., \& Surip, N. (2018). Pengaruh Kompensasi dan Kepuasan Kerja terhadap Employee Engagement yang Berdampak pada Turnover Intentions. Jurnal Manajemen Ilmiah Bisnis, 4(1), $117-131$.

Ahmed, U. (2019). Job Demands and Work Engagement: Call for More Urgent Empirical Attention. Annals of Contemporary Developments in Management \& HR, 1(2), 8-14. https://doi.org/10.33166/acdmhr.2019.02.002

Akgunduz, Y., Alkan, C., \& Gök, Ö. A. (2018). Perceived Organizational Support, Employee Creativity and Proactive Personality: The Mediating Effect of Meaning of Work. Journal of Hospitality and Tourism Management, 34, 105-114. https://doi.org/10.1016/j.jhtm.2018.01.004

Al Adresi, A., \& Darun, M. R. (2017). Investigating Mediating Effect of Perceived Organizational Support Between SHRM Practices and Employee Trust. International Journal of Engineering Business Management, 9, 1-10. https://doi.org/10.1177/1847979017701131

Ali, S., \& Farooqi, Y. A. (2014). Effect of Work Overload on Job Satisfaction, Effect of Job Satisfaction on Employee Performance and Employee Engagement (A Case of Public Sector University of Gujranwala Division ). International Journal of Multidisciplinary Sciences and Engineering, 5(8), 23-30.

Amor, A. M., Vázquez, J. P. A., \& Faíña, J. A. (2019). Transformational Leadership and Work Engagement: Exploring The Mediating Role of Structural Empowerment. European Management Journal, 1-10. https://doi.org/10.1016/j.emj.2019.06.007

Andamari, S. R. (2019). Analisis Faktor Kepemimpinan Otentik dan Persepsi Dukungan Organisasi pada Work Engagement Staf Organisasi Perhotelan dengan Efikasi Diri sebagai Mediatornya. Jurnal Psikologi Integratif, 7(2), 131-152. https://doi.org/10.14421/jpsi.v7i2.1775

Asbari, M., Bernarto, I., Pramono, R., Purwanto, A., Hidayat, D., Sopa, A., ... Mustofa. (2020). The Effect of Work-Family Conflict on Job Satisfaction and Performance: A Study of Indonesian Female Employees. International Journal of Advanced Science and Technology, 29(3), 67246748 .

Ayu, D. R., Maarif, S., \& Sukmawati, A. (2015). Pengaruh Job Demands, Job Resources dan Personal Resources terhadap Work Engagement. Jurnal Aplikasi Bisnis Dan Manajemen, 1(1), 12-22. https://doi.org/10.17358/jabm.1.1.12

Bakker, A. B., \& Demerouti, E. (2017). Job Demands-Resources Theory: Taking Stock and Looking Forward Job Demands - Resources Theory: Taking Stock and Looking Forward. Journal of Occupational Health Psychology At 20, 22(3), 273-285.

Burić, I., \& Moè, A. (2020). What Makes Teachers Enthusiastic: The Interplay of Positive Affect, SelfEfficacy and Job Satisfaction. Teaching and Teacher Education, 89, 1-10. https://doi.org/10.1016/j.tate.2019.103008

Caesens, G., \& Stinglhamber, F. (2014). The Relationship between Perceived Organizational Support and Work Engagement: The Role of Self-Efficacy and Its Outcomes. Revue Europeenne de Psychologie Appliquee, 64(5), 259-267. https://doi.org/10.1016/j.erap.2014.08.002

Caesens, Gaëtane, Stinglhamber, F., Demoulin, S., \& De Wilde, M. (2017). Perceived Organizational Support and Employees Well-Being: The Mediating Role of Organizational Dehumanization. European Journal of Work and Organizational Psychology, 26(4), 1-46. 
https://doi.org/10.1080/1359432X.2017.1319817

Crawford, E. R., LePine, J. A., \& Rich, B. L. (2010). Linking Job Demands and Resources to Employee Engagement and Burnout: A Theoretical Extension and Meta-Analytic Test. Journal of Applied Psychology, 95(5), 834-848. https://doi.org/10.1037/a0019364

Dewantara, M. T., \& Wulanyani, N. M. S. (2019). Pengaruh Kepuasan Kerja dan Keadilan Organisasional terhadap Keterikatan Karyawan Hotel Swasta X di Bali. Jurnal Psikologi Udayana, 6(2), 312-319. https://doi.org/10.24843/jpu.2019.v06.i02.p10

Dicke, T., Marsh, H. W., Parker, P. D., Guo, J., Riley, P., \& Waldeyer, J. (2019). Job Satisfaction of Teachers and their Principals in Relation to Climate and Student Achievement Abstract. Journal of Educational Psychology, 1-37.

Dwitasari, A. I., Ilhamuddin, \& Widyasari, S. D. (2015). Pengaruh Perceived Organizational Support dan Organizational-Based Self Esteem terhadap Work Engangement. Jurnal Mediapsi, 1(1), 4050. https://doi.org/10.21776/ub.mps.2015.001.01.5

Eldor, L. (2016). Work Engagement: Toward a General Theoretical Enriching Model. Human Resource Development Review, 15(3), 317-339. https://doi.org/10.1177/1534484316655666

Elst, T. Vander, Cavents, C., Daneels, K., Johannik, K., Baillien, E., Van den Broeck, A., \& Godderis, L. (2016). Job Demands-Resources Predicting Burnout and Work Engagement among Belgian Home Health Care Nurses: A Cross-Sectional Study. Nursing Outlook, 64(6), 542-556. https://doi.org/10.1016/j.outlook.2016.06.004

Fatmasari, E., Al, M. M., \& Wulida, A. T. (2018). The Effect of Quality of Work-Life and Motivation on Employee Engagement With Job Satisfication as an Intervening Variabel. RJOAS, 2(74), 108114.

Fazlurrahman, H., Wijayanti, D. T., Hadi, H. K., Rahman, Z., Nugrohoseno, D., \& Rahman, M. F. W. (2020). Analysis of Work Engagement Measurement at Work From Home Due to The Effect Of Covid-19 Pandemic. Technium Social Sciences Journal, 14, 363-375.

Ghozali, I. (2016). Aplikasi Analisis Multivariate Dengan Program IBM SPSS 25 (edisi 9). Semarang: Badan Penerbit Universitas Diponegoro.

Goldin, C. (2003). Human capital. Economics and Human Biology, 1(2), 207-221. https://doi.org/10.1016/S1570-677X(03)00035-2

Green, P. I., Finkel, E. J., Fitzsimons, G. M., \& Gino, F. (2017). The Energizing Nature of Work Engagement: Toward A New Need-Based Theory of Work Motivation. Research in Organizational Behavior, 37, 1-18. https://doi.org/10.1016/j.riob.2017.10.007

Guglielmi, D., Avanzi, L., Chiesa, R., Mariani, M. G., Bruni, I., \& Depolo, M. (2016). Positive Aging in Demanding Workplaces: The Gain Cycle between Job Satisfaction and Work Engagement. Frontiers in Psychology, 7, 1-10. https://doi.org/10.3389/fpsyg.2016.01224

Humairoh, \& Wardoyo. (2017). Analisis Pengaruh Budaya Organisasi terhadap Employee Engagement dengan Kepuasan Kerja sebagai Variabel Intervening. Jurnal Manajemen, 9(1), 1-21. https://doi.org/10.31937/manajemen.v9i1.594

Imran, M. Y., Elahi, N. S., Abid, G., Ashfaq, F., \& Ilyas, S. (2020). Impact of perceived organizational support on work engagement: Mediating mechanism of thriving and flourishing. Journal of Open Innovation: Technology, Market, and Complexity, 6(82), 1-18. 
Muhammad Mudrik Fairnandha. Pengaruh Perceived Organizational Support, Job Demands, dan Job Satisfaction terhadap Work Engagement

https://doi.org/10.3390/JOITMC6030082

Jazilah, B. (2020). Analisis Pengaruh Job Demand terhadap Work Engagement melalui Burnout. Jurnal Ilmu Manajemen, 8(3), 1038-1049.

Jin, M. H., \& McDonald, B. (2017). Understanding Employee Engagement in the Public Sector: The Role of Immediate Supervisor, Perceived Organizational Support, and Learning Opportunities. American Review of Public Administration, 47(8), 881-897. https://doi.org/10.1177/0275074016643817

Kuok, A. C. H., \& Taormina, R. J. (2017). Work engagement: Evolution of The Concept and A New Inventory. Psychological Thought, 10(2), 262-287. https://doi.org/10.5964/psyct.v10i2.236

Lopes, S., Chambel, M. J., Castanheira, F., \& Oliveira-Cruz, F. (2015). Measuring Job Satisfaction in Portuguese Military Sergeants and Officers: Validation of The Job Descriptive Index and The Job in General Scale. Military Psychology, 27(1), 52-63. https://doi.org/10.1037/mil0000060

Mäkikangas, A., Leiter, M. P., Kinnunen, U., \& Feldt, T. (2020). Profiling Development of Burnout Over Eight Years: Relation with Job Demands and Resources. European Journal of Work and Organizational Psychology, 1-12. https://doi.org/10.1080/1359432X.2020.1790651

Man, G. S., \& Hadi, C. (2013). Hubungan Antara Perceived Organizational Support dengan Work Engagement pada Guru SMA Swasta di Surabaya. Jurnal Psikologi Industri Dan Organisasi, 2(2), 90-99.

Maria, A. S., Wörfel, F., Wolter, C., Gusy, B., Rotter, M., Stark, S., ... Renneberg, B. (2017). The Role of Job Demands and Job Resources in the Development of Emotional Exhaustion, Depression, and Anxiety Among Police Officers. Police Quarterly, 21(1), 1-26. https://doi.org/10.1177/1098611117743957

Mishra, D. P. K. (2013). Job Satisfaction. Journal of Humanities and Social Science, 14(5), 45-54. https://doi.org/10.9790/1959-1454554

Mokhtar, D., Abdullah, N. A., \& Roshaizad, N. A. (2020). Survey Dataset on Presenteeism, Job Demand and Perceived Job Insecurity: The Perspective of Diplomatic Officers. Data in Brief, 30, 1-6. https://doi.org/10.1016/j.dib.2020.105505

Mujiasih, E. (2015). Hubungan Antara Persepsi Dukungan Organisasi (Perceived Organizational Support) dengan Keterikatan Karyawan. Jurnal Psikologi Undip, 14(1), 40-51. https://doi.org/10.14710/jpu.14.1.40-51

Najeemdeen, I. S., Abidemi, B. T., Rahmat, F. D., \& Bulus, B. D. (2018). Perceived Organizational Culture and Perceived Organizational Support on Work Engagement. Academic Journal of Economic Studies, 4(3), 199-208.

Nugroho, A. S., \& Savira, S. I. (2019). Hubungan Antara Efikasi Diri dengan Work Engagement pada Guru yang Memiliki Sertifikasi di SMPN Kecamatan Nganjuk. Character: Jurnal Penelitian Psikologi, 06(2), 1-4.

Prabowo, N. S., \& Fathoni, A. (2017). Pengaruh Kepuasan Kerja dan Stres Kerja terhadap Engagement Employee dengan Turnover Intention sebagai Variabel Intervening pada PT Ara Shoes Semarang. Jurnal Unpad, 75-79.

Rais, I. S., \& Parmin. (2020). Pengaruh Perceived Organizational Support dan Budaya Organisasi Terhadap Employee Engagement dengan Kepuasan Kerja Sebagai Variabel Intervening. Jurnal 
Ilmiah Mahasiswa Manajemen, Bisnis Dan Akuntansi (JIMMBA), 2(5), 813-833. https://doi.org/10.32639/jimmba.v2i5.654

Ramdhani, G. F., \& Ratnasawitri, D. (2017). Hubungan Antara Dukungan Organisasi dengan Keterikatan Kerja pada Karyawan PT. X Di Bogor. Jurnal Empati, 6(1), 199-205.

Rugiyanto. (2018). Pengaruh Self Efficacy dan Kepuasan Kerja terhadap Employee Engagement (Keterikatan Kerja) pada Guru SMK Negeri Kota Administrasi Jakarta Utara. Jurnal Manajemen Pendidikan, 9(2), 111-120.

Upadyaya, K., Vartiainen, M., \& Salmela-Aro, K. (2016). From Job Demands and Resources to Work Engagement, Burnout, Life Satisfaction, Depressive Symptoms, and Occupational Health. Burnout Research, 3(4), 1-19. https://doi.org/10.1016/j.burn.2016.10.001

Vorina, A., Simonič, M., \& Vlasova, M. (2017). An Analysis of the Relationship Between Job Satisfaction and Employee Engagement. Economic Themes, 55(2), 243-262. https://doi.org/10.1515/ethemes-2017-0014

Wahyuni, I., \& Sulastri. (2020). Pengaruh Perceived Organizational Support terhadap Organizational Citizenship Behavior dengan Work Engagement sebagai Variabel Pemediasi. Jurnal Kajian Manajemen Dan Wirausaha, 2(1), 10-17. https://doi.org/10.24036/jkmw0284880

Widjaja, J., \& Devie. (2014). Pengaruh Job Satisfaction terhadap Financial Performance melalui Employee Engagement dan Competitive Advantage Sebagai Intervening Variable pada Perusahaan Retail Publik di Surabaya. Business Accounting Review, 2(2), 99-110.

Wijayati, D. T., Fazlurrahman, H., Hadi, H. K., Rahman, Z., \& Kautsar, A. (2020). Coaching as Determinant of Job Performance: Co-working Support as Mediating Variable. KnE Social Sciences, 240-250. https://doi.org/10.18502/kss.v4i7.6855

Yeh, H. J. (2015). Job Demands, Job Resources, and Job Satisfaction in East Asia. Social Indicators Research, 121(1), 47-60. https://doi.org/10.1007/s11205-014-0631-9

Yulianti, P., \& Puteri, E. A. H. (2016). Peran Mediasi Affective Commitment pada Hubungan Procedural Justice, Perceived Organizational Support dengan Employee Engagement. Jurnal Ilmu Ekonomi \& Sosial, 7(1), 14-27.

Zagenczyk, T. J., Purvis, R. L., Cruz, K. S., Thoroughgood, C. N., \& Sawyer, K. B. (2020). Context and Social Exchange: Perceived Ethical Climate Strengthens the Relationships Between Perceived Organizational Support and Organizational Identification and Commitment. International Journal of Human Resource Management, 1-20. https://doi.org/10.1080/09585192.2019.1706618 